\title{
Seaweed extract to enhance marigold seed germination and seedling establishment
}

\author{
Armando Reis Tavares ${ }^{1}$ (D) Patrick Luan F. dos Santos ${ }^{2}$ (D) Alessandro Reinaldo Zabotto ${ }^{2}$ (ID)

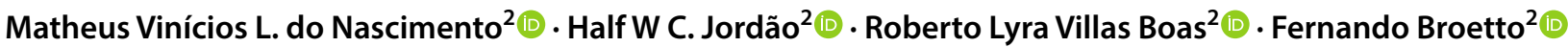

Received: 18 March 2020 / Accepted: 28 September 2020 / Published online: 8 October 2020

(c) Springer Nature Switzerland AG 2020

\begin{abstract}
The brown seaweed Ascophyllum nodosum and seaweed-derived products have been widely used as nutrient additions, biofertilizer and biostimulant in horticultural crop systems. This study aimed to evaluate the effects of a seaweed extract obtained from whole brown algae (A nodosum) on seed germination and seedling growth of ornamental marigold (Tagetes erecta). The seeds of marigold were daily sprayed with 0 (control), 5, 10 or $15 \mathrm{~mL} \mathrm{~L}^{-1}$ commercial seaweed extract Acadian Seaplants ${ }^{\mathrm{TM}}(70 \mathrm{ml})$. The percentage, index and average time of seed germination, seedling height, fresh, dry mass of shoots, roots and root system morphology were evaluated. The results showed that the seaweed extract enhanced all parameters related to seed germination and seedling growth and development. The best results were obtained with $15 \mathrm{~mL} \mathrm{~L}^{-1}$ seaweed extract which increased by two-fold marigold seed germination and $84.00 \%$ seedling height, and both fresh and dry shoot mass and root morphology. We suggest algal extracts of Ascophyllum nodosum should be used as natural biostimulant on marigold crop, improving seed germination and seedling development.
\end{abstract}

Keywords Ascophyllum nodosum $\cdot$ Tagetes erecta $\cdot$ Floriculture root development $\cdot$ Plant growth

\section{Introduction}

The concept of sustainability and sustainable products has become a potential market for many companies and a thematic area of study at many universities. To reduce dependence on synthetic chemicals natural products have been used in Brazilian agriculture as a new method of ensuring the sustainability and production of agriculture yields [1, 2]. Biostimulants, such as Ascophyllum nodosum seaweed extract, are a sustainable alternative to stimulate root growth, seedling development and, at the same time, reduce production costs. However, to maximize biostimulant effects it must be applied correctly $[3,4]$.

Seaweed extracts are considered as a full-fledged class of agri-inputs and highly attractive business opportunity once these substances mitigate abiotic stress and improve plant productivity [5]. Brown algae are the most used in agriculture, improving various growth parameters, increased water and nutrient uptake, resistance to abiotic stress, in addition stimulating seed germination [6]. The benefits of seaweed extract as biostimulants range from the sustainable yield production to the improvement of physiological processes in a variety of crops and species. Brazilian floriculture is an innovative and technologically responsive segment to the new trends, especially based on the achievement of farm sustainability [7].

Brazilian ornamental floriculture exports are focused on vegetative propagation, such as seedlings and ornamental plants, bulbs, tubers, rhizomes and cut flowers representing $6.71 \%$ of international sales [8]. The Brazilian floriculture

Fernando Broetto, fernando.broetto@unesp.br; Armando Reis Tavares, atavares2005@yahoo.com.br; Patrick Luan F. dos Santos, patricklfsantos@gmail.com; Alessandro Reinaldo Zabotto, alezabotto@gmail.com; Matheus Vinícios L. do Nascimento, matheus.vln@ hotmail.com; Half W C. Jordão, halfwberg@gmail.com; Roberto Lyra Villas Boas, rolvboas@gmail.com | Instituto Agronômico de Campinas (IAC), Jundiai, , São Paulo, Brazil. ²Universidade Estadual Paulista (UNESP), Botucatu, , São Paulo, Brazil. 
production is concentrated on the domestic market at about $96.5 \%$ mainly driven by landscaping, gardening, and meeting the demand for holidays with only a small portion intended for export [9]. In this context, we highlight Tagetes spp., popularly known as marigold. These species are noteworthy for the exuberance of the inflorescences with attractive colors, congregated in chapter form that is appreciated as garden ornamentation [10-12]. Marigold is easy to cultivate due to its adaptability to different soils and climatic conditions [13]. However, seed quality decrease under ambient storage conditions; consequently, seed germination and seedlings emergence and establishment of marigold are slow and very inconsistent, especially under warm or cool conditions [14]. Direct sowing on substrate results in irregular germination, slow emergence, and deficient seedling establishment [15]. Marigold seeds germination can be preserved by drying the seeds to $8 \%$ moisture and maintained in sealed packages or silica gel [16]. The focus of the present study was to investigate the effect of seaweed-based extract in not only overcoming the above obstacles but also improving seed germination.

\section{Material and methods}

The experiment was conducted at São Paulo State University, Department of Agricultural Sciences, Botucatu, São Paulo State, Brazil ( $22^{\circ} 58^{\prime} \mathrm{S}-48^{\circ} 23^{\prime} \mathrm{W}, 765 \mathrm{~m}$ asl). The concentrations of $0,5,10$ or $15 \mathrm{ml} \mathrm{L}^{-1}$ of commercial Ascophyllum nodosum seaweed extract (Acadian Seaplants ${ }^{\mathrm{TM}}$ ) were prepared by its dilution in water. The commercial marigold seeds were sown in polyethylene trays (128 cells) filled with commercial substrate (Table 1 ).

The marigold seeds were sprayed daily in the morning with $70 \mathrm{ml}$ of each concentration of seaweed extract. The experimentation was carried out in greenhouse in ambient conditions $\left(20.54^{\circ} \mathrm{C}\right.$ temperature, $\min 16.5^{\circ} \mathrm{C}$ and max. $25.3^{\circ} \mathrm{C} ; 77,90 \%$ relative humidity, $\min .59 .1 \%$ and $\max$. $93.6 \%$ ) for a period of 30 days and variables analyzed were:

Percentage of Germination (\%) calculated using relation (Eq. 1)

$\mathrm{PG}=\left(\frac{n}{t}\right) \times 100$

$n=$ number of germinated seeds at the end of experimentation (seedlings with height of at least $2 \mathrm{~mm}$ were considered as germinated) and $t=$ total number of seeds;
Germination Speed Index (GSI) calculated using relation (Eq. 2).

$\mathrm{GSI}=\sum \frac{n i}{t i}$

$\mathrm{ni}=$ number of seeds germinated during 30 days ' $i$ ', and $\mathrm{ti}=$ time after test installation [17]

Mean Time to Germination-MTG (days) calculated using relation (Eq. 3).

MTG $=\frac{\left(\sum n i . t i\right)}{n i}$

$n i=$ number of germinated seeds per day, and $t i=$ time after test installation [18].

After seed germination the variables seedling height, fresh, dry mass of shoot and roots of seedlings were analyzed. The length and diameter of the roots were also evaluated utilizing the WinRhizo image analysis system.

The experiment was a completely randomized design with 4 seaweed extracts treatments and 10 replications (each with 10 seeds). Data were submitted to the Shapiro-Wilk normality test and subjected to the test of significance using one-way analysis of variance (ANOVA) and, the difference were compared by polynomial regression analysis $(p \leq 0.05)$.

\section{Results and discussion}

Results show that all germination variables increased as biostimulant concentrations increased $(p \leq 0.01)$ (Table 2). Percentage of germination (PG) values ranged from 24 to $84 \%$ with a linear and positive regression (Fig. 1). Similar data were obtained with seaweed extracts on seed germination of Chicoria (Cichorium endivia) [19], and ornamental

Table $2 \mathrm{~F}$ values and coefficient of variation for percentage of germination (PG), germination speed index (GSI), average time of germination (MTG) of biostimulant treatments

\begin{tabular}{llll}
\hline & PG\% & GSI & MTG days \\
\hline$F$ & $133.89^{* *}$ & $73.90^{* *}$ & $3.82^{*}$ \\
$\mathrm{CV}(\%)$ & 14.00 & 26.20 & 26.64 \\
\hline
\end{tabular}

$\mathrm{ns}, *$ and ${ }^{* *}$ is, respectively, not significant, significant at $(p \leq 0.05)$ and $(p \leq 0.01)$ probability by $F$ test. adm.-adminesional
Table 1 Substrate (mix of peat sphagnum, expanded vermiculite, roasted and rice husks macro and micronutrients) chemical analyses

\begin{tabular}{|c|c|c|c|c|c|c|c|c|c|c|c|c|c|c|c|}
\hline $\mathrm{N}$ & $\mathrm{P}_{2} \mathrm{O}_{5}$ & $\mathrm{~K}_{2} \mathrm{O}$ & $\mathrm{Ca}$ & $\mathrm{Mg}$ & $S$ & Moisture & O.M. & C.O. & $\mathrm{Na}$ & $\mathrm{Cu}$ & $\mathrm{Fe}$ & $\mathrm{Mn}$ & $\mathrm{Zn}$ & $\mathrm{C} / \mathrm{N}$ & $\mathrm{pH}$ \\
\hline $\begin{array}{l}---\% \\
-\end{array}$ & 6 (natu & ral)----- & & & & & & dry & $\mathrm{mg} / \mathrm{kc}$ & (nat & |)--- & & & & atu \\
\hline 0.79 & 0.4 & 0.15 & 1.14 & 2.55 & 0.15 & 8 & 59 & 36 & 1,369 & 24 & 9,133 & 138 & 44 & $42 / 1$ & 5.8 \\
\hline
\end{tabular}



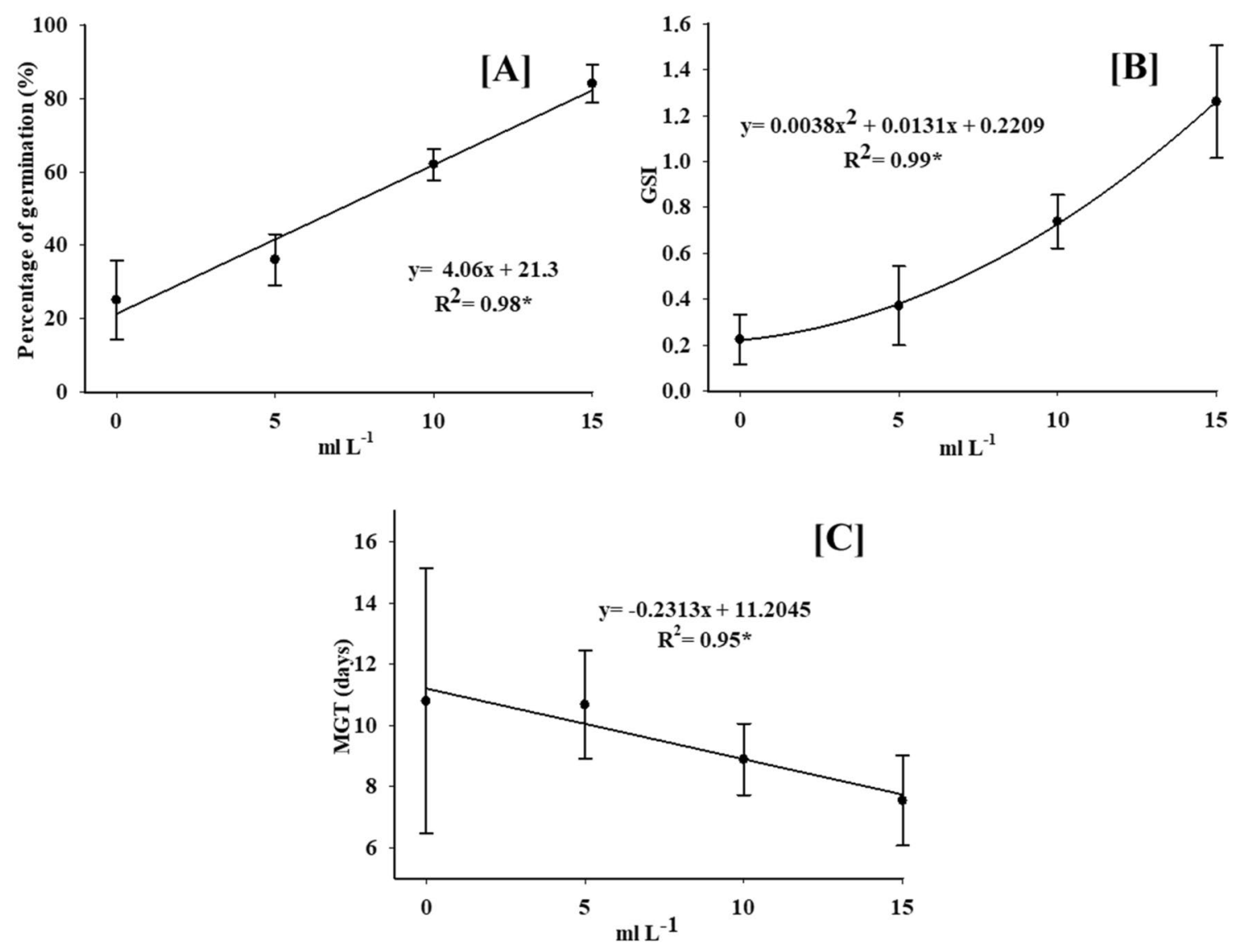

Fig. 1 Percentage of germination PG [A], Germination Speed Index (GSI) [B] and Mean Germination Time (MGT) [C] of marigold. * significant $(p \leq 0.05)$

sunflower (Helianthus annuus) [4]. However, higher concentrations of seaweed extract were found to decrease the percentage of germination of parsley (Petroselinum sativum) seeds [20].

Treatment with $15 \mathrm{~g} \mathrm{~L}^{-1}$ biostimulant enhanced by two-fold (84\%) marigold seed germination in relation to control. Germination percentage reported here is higher than that reported for Tagetes erecta (39-66.96\%) [21]. GSI showed a quadratic and positive regression, while MGT showed a linear and negative regression (Fig. 1); accordingly, higher germination speed induced a decrease in emergence time of the seedlings. Treatment with $15 \mathrm{~g} \mathrm{~L}^{-1}$ biostimulant decreased the MGT (7.5 days) with high GSI (1.26) and higher seed PG (84\%). A. nodosum extracts consist of cytokines, auxins, abscisic acid, gibberellins, betaines and alginates [22], and under optimal concentration, these extracts can increase seedling production [23], as well as improve seed germination and seedling establishment [4], as observed in our study (Fig. 1). Treatment with $15 \mathrm{~g} \mathrm{~L}^{-1}$ biostimulant can favor the development of marigold plants by modulating seedling growth and facilitating its early establishment which would increasing their survivability; once, fully developed plants are more resistant to adverse environmental conditions [4].

The biostimulant increased seed germination and, consequently, seedling development (Figs. 2 and 3). The biometric parameters of shoot, root and WinRhizo showed statistically significant difference $(p \leq 0.01)$, excluding the root dry mass variable (Table 3 ). The data in Fig. 2 showed that seedling development increased along with the increase in biostimulant, and the best result was achieved with $15 \mathrm{ml} \mathrm{L}^{-1}$ biostimulant. Seedling height increased $84.00 \%$ compared to control treatment. Similar results were also reflected in the increase of fresh and dry mass of shoots. With few data on marigold in the literature, these values are essential to the successful programming of ornamental plant production.

The tallest plants were observed after treatment with $15 \mathrm{ml} \mathrm{L}^{-1}$ biostimulant, which was within the range of $6.18-12.12 \mathrm{~cm}$ in marigold seedlings 30 days after germination [21]. Seaweed extracts are able to increase gene expression of endogenous auxins and cytokines [24], which can be correlated with the increase of mass in marigold. By their cytokine constituents, $A$. nodosum extracts 

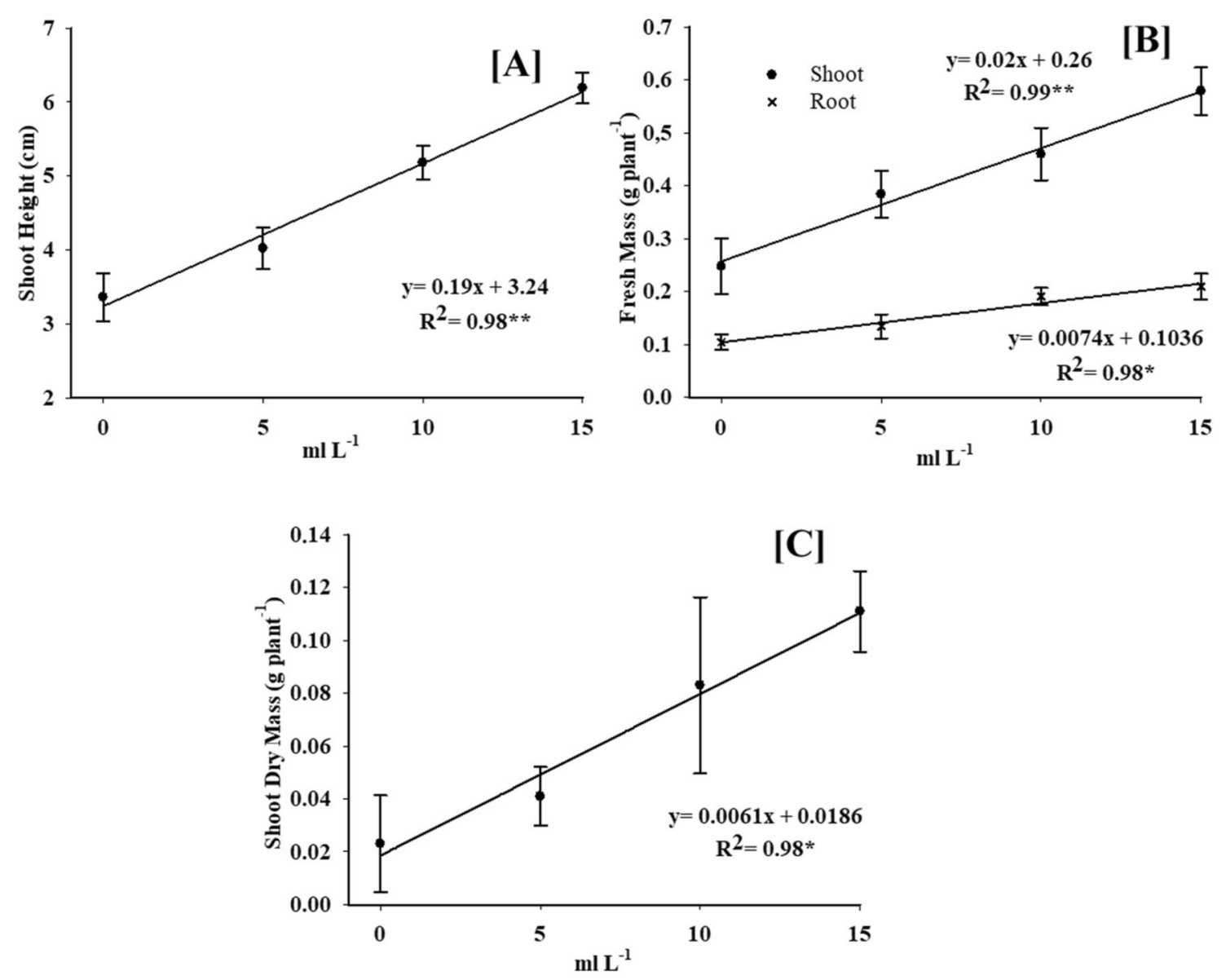

Fig. 2 Shoot height $[A]$, Shoot and root fresh mass $[B]$ and Shoot dry mass $[C]$ of marigold. * and ${ }^{* *}$ is, respectively, significant at $(p \leq 0.05)$ and $(p \leq 0.01)$
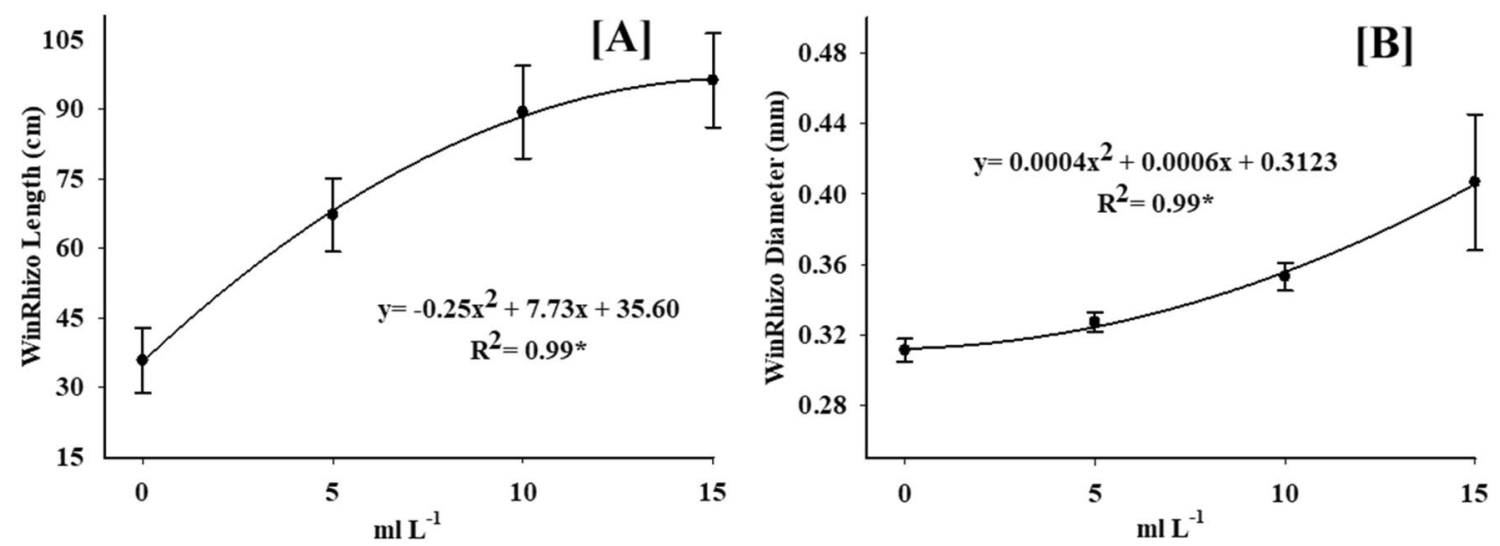

Fig. 3 Root Length $[A]$ and Diameter $[B]$ of marigold. * significant at $(p \leq 0.05)$

can augment cell division, promoting cellular expansion, consequently increasing fresh and dry mass [23]. A. nodosum extracts also contain macro- and micronutrients [5], stimulating seedling growth; however, if the plant is effectively fertilized, the extract may not be as effective on plant growth [25]. The increase of mass by A. nodosum extracts is described in diverse studies $[4,15]$.

Root morphology data showed a quadratic and negative regression for length (Fig. $3 \mathrm{a}$ ) and quadratic and positive regression for diameter (Fig. $3 \mathrm{~b}$ ). These data 
Table 3 F values and coefficient of variation for Shoot (Height, fresh-FM and dry-DM mass), Root (Fresh and dry mass) and WinRhizo (Length and Diameter) according to the concentrations

\begin{tabular}{|c|c|c|c|c|c|c|c|}
\hline & \multicolumn{3}{|l|}{ Shoot } & \multicolumn{2}{|l|}{ Root } & \multicolumn{2}{|c|}{ WinRhizo } \\
\hline & Height & FM & DM & FM & DM & Length & Diameter \\
\hline$F$ & $225.53^{* *}$ & $83.43^{* *}$ & $35.40^{* *}$ & $59.38^{* *}$ & $2.69^{\mathrm{ns}}$ & $28.22^{* *}$ & $12.89^{* *}$ \\
\hline CV (\%) & 5.63 & 11.54 & 32.89 & 12.55 & 46.35 & 12.27 & 5.76 \\
\hline
\end{tabular}

ns, * and ** is, respectively, not significant, significant at $(p \leq 0.05)$ and $(p \leq 0.01)$ probability by $F$ test

corroborate data showing that seaweed biostimulant contains auxins [22] and that this hormone increases root development [26]. Moreover, auxins, together with cytokines, anticipate and accelerate root formation [23]. Thus, the application of seed extract enhances marigold physiological performance, increasing seed germination and seedling development. However, the use of algae extract had no effect on root morphology of Passiflora actinia [27] and ornamental sunflower seedlings [4].

A. nodosum extract promotes root development and, consequently, serves to effectively establish the seedling [23]. In the present study, the concentration of $15 \mathrm{ml} \mathrm{L}^{-1}$ biostimulant was sufficient to promote seed germination (Fig. 1) as well as seedling (Fig. 2) and root (Fig. 3) development. However, more detailed studies on the use of $A$. nodosum algae extract as a biostimulant should be performed. The effects of extracts can be attributed to their hormonal content, nutrient value, and/or the presence of alga-specific polysaccharides, betaines, polyamines, and phenolic compounds with phenotypic effects [28].

\section{Conclusions}

Seed germination and seedling development of marigold were enhanced with Ascophyllum nodosum extract. The concentration $15 \mathrm{ml} \mathrm{L}^{-1}$ seaweed is recommended for marigold. However, seaweed extracts are complex composts, and further studies are recommended to elucidate the exact mechanism of action involved in seed germination and plant initial growth.

\section{Compliance with ethical standards}

Conflict of interest No conflicts of interest

\section{References}

1. Moraes A, Carvalho PCF, Lustosa SBC, Lang CR, Deiss L (2014) Research on Integrated crop-livestock systems in Brazil. Rev Ciência Agr 45:1024-1031
2. Leite $A E$, De Castro R, Jabbour CJC, Batalha MO, Govindan $K$ (2014) Agricultural production and sustainable development in a Brazilian region (Southwest, São Paulo State): motivations and barriers to adopting sustainable and ecologically friendly practices. Intern J Sust Develop World Ecol 21:422-429

3. Ali O, Ramsubhag A, Jayaraman J (2019) Biostimulatory activities of Ascophyllum nodosum extract in tomato and sweet pepper crops in a tropical environment. PLoS ONE 14:e0216710

4. Santos PLF, Zabotto AR, Jordão HWC, Boas RLV, Broetto F, Tavares AR (2019) Use of seaweed-based biostimulant (Ascophyllum nodosum) on ornamental sunflower seed germination and seedling growth. Ornam Hort 25:231-237

5. Boukhari EL, ME, Barakate M, Bouhia Y, Lyamlouli K, (2020) Trends in seaweed extract based biostimulants: manufacturing process and beneficial effect on soil-plant systems. Plants 9:359

6. Dapper TB, Pujarra S, Oliveira AJ, Oliveira FG, Paulert R (2014) Potencialidades das macroalgas marinhas na agricultura: revisão. Rev Agroneg Meio Amb 7:295-313

7. Junqueira AH, Peetz MDS (2018) Sustainability in Brazilian floriculture: introductory notes to a systemic approach. Ornam Hort 24:155-162

8. Duran R (2013) Flowers Market in Brazil. https://thebrazilbusine ss.com/article/flowers-market-in-brazil. Accessed 31 July 2020.

9. SEBRAE (2015) Flores e plantas ornamentais do Brasil. Série de estudos mercadológicos, SEBRAE, Brasília, Brazil

10. Coelho LC, Kawamoto LS, Rodas CL, Souza GA, Pinho PJ, Carvalho JG (2011) Caracterização de sintomas visuais, parâmetros de crescimento e desenvolvimento de Tagetes erecta sob deficiências nutricionais. Agrarian 4:113-122

11. Gupta R, Yadav A, Garg VK (2014) Influence of vermicompost application in potting media on growth and flowering of marigold crop. Int J Recycl Org Waste Agr 3:47

12. Lorenzi $\mathrm{H}$ (2015) Plantas para jardim no Brasil: herbáceas, arbustivas e trepadeiras. Instituto Plantarum, Nova Odessa, Brazil

13. Basit A, Shah K, Rahman MU, Xing L, Zuo X, Han M, Alam N, Khan F, Ahmad I, Khalid MA (2018) Salicylic acid an emerging growth and flower inducing hormone in marigold (Tagetes $s p$. L.). Pure Appl Biol 7(4):1301-1308

14. Afzal I, Ashraf S, Qasim M, Basra SMA, Shahid M (2009) Does halopriming improve germination and seedling vigor in marigold. Seed Sci Technol 37:436-445

15. Mukhtar K, Afzal I, Qasim M, Basra SMA, Shahid M (2013) Does priming promote germination and early stand establishment of French marigold (Tagetes patula L.) seeds by inducing physiological and biochemical changes. Acta Sci Pol Hortorum Cultus 12(3):13-21

16. Rao CC, Dadlani NK, Dadlani M (2003) Maintenance and enhancement of germination and vigour in Marigold (Tagetes spp.) seed. Seed Sci Technol 31(3):745-751

17. Maguirre JD (1962) Speed of germination-aid in selection and evaluation for seedling emergence and vigor. Crop Sci 2:176-177 
18. Labouriau LG (1983) A germinação das sementes. OEA, Washington

19. Ferraz A, Silva VN, Radunz AL (2019) Condicionamento fisiológico de sementes de chicória com Ascophyllum nodosum. Rev Ciênc Agron 28:215-226

20. Sorgatto KP, Silva VN (2019) Embebição de sementes de salsa com Ascophyllum nodosum: efeitos na germinação e crescimento de plântulas sob estresse térmico. Acta Biol Catar 5:98-106

21. Zanello CA, Cardoso JC (2016) Resíduo de grama como substrato para o cultivo orgânico de flores. Rev Ciênc Tecnol Amb 3:36-42

22. Mackinnon SL, Hiltz D, Ugarte R, Craft CA (2010) Improved methods of analysis for betaines in Ascophyllum nodosum and its commercial seaweed extracts. J Appl Phycol 22:489-494

23. Neumann ER, Resende JT, Camargo LKP, Chagas RR, Lima Filho RBL (2017) Produção de mudas de batata doce em ambiente protegido com aplicação de extrato de Ascophyllum nodosum. Hort Bras 35:490-498

24. Rayorath $P$, Jithesh M, Farid A, Khan W, Palanisamy R, Hankins SD, Critchley AT, Prithiviraj B (2008) Rapid bioassays to evaluate the plant growth promoting activity of Ascophyllum nodosum (L.) Le Jol. using a model plant, Arabidopsis thaliana (L.) Heynh. J Appl Phycol 20:423-429
25. Galindo FS, Teixeira Filho MCM, Buzetti S, Alves CJ, Garcia CMP, Nogueira LM (2019) Extrato de algas como bioestimulante na nutrição e produtividade do trigo irrigado na região de Cerrado. Colloq Agric 15:130-140

26. Taiz L, Zeiger E (2017) Fisiologia e desenvolvimento vegetal. Editora Artmed, Porto Alegre

27. Gomes EN, Vieira LM, Tomasi JDC, Tomazzoli MM, Grunennvaldt RL, Fagundes CDM, Machado RCB (2018) Brown seaweed extract enhances rooting and roots growth on Passiflora actinia Hook stem cuttings. Ornam Hort 24:269-276

28. De Saeger J, Van Praet S, Vereecke D, Park J, Jacques S, Han T, Depuydt S (2020) Toward the molecular understanding of the action mechanism of Ascophyllum nodosum extracts on plants. J Appl Phycol 32:573-597

Publisher's Note Springer Nature remains neutral with regard to jurisdictional claims in published maps and institutional affiliations. 